\title{
The Role of Poverty in California Teenagers' Fatal Traffic Crash Risk
}

\author{
Mike Males \\ Center on Juvenile and Criminal Justice; YouthFacts.org
}

\begin{abstract}
Teenagers' high rates of motor vehicle crashes, accounting for $40 \%$ of external deaths among 16-19 yearolds, have been ascribed largely to inherent "adolescent risk-taking" and developmental hazards. However, the fact that compared to adults 25 and older, teenagers are twice as likely to live in poverty and low-income areas, risk factors for many types of violent death, has not been assessed. This paper uses Fatality Analysis Reporting System data on 65,173 fatal motor vehicle crashes by drivers in California's 35 most populous counties for 1994-2007 to analyze fatal crash involvements per 100 million miles driven by driver age, county, poverty status, and 15 other traffic safety-related variables. Fatal crash rates were substantially higher for every driver age group in poorer counties than in richer ones. Multivariate regression found socioeconomic factors, led by the low levels of licensing and high unemployment rates prevalent in low-income areas, were associated with nearly $60 \%$ of the variance in motor vehicle crash risks, compared to $3 \%$ associated with driver age. The strong association between fatal crash risk and poverty, especially for young drivers who are concentrated in high-poverty brackets and low-income areas, suggests that factors related to poorer environments constitute a major traffic safety risk requiring serious attention.
\end{abstract}

(C) 2009 Californian Journal of Health Promotion. All rights reserved.

Keywords: adolescent risk, motor vehicle accident, poverty, socioeconomics

\section{Introduction}

Motor vehicle fatalities, comprising $41 \%$ of California teenagers' external deaths compared to $24 \%$ for adults, represent the widest gap between adolescents' and adults' non-natural mortality (EPICenter, 2008). Researchers typically ascribe teenagers' high rates of traffic casualty to factors allegedly innate to adolescence: developmental immaturity, peer influences, and biologically-impelled risk-taking (Steinberg, 2007; National Research Council, 2006; Hedlund, Shults, \& Compton, 2003; Blum, Beuhring, \& Rinehart, 2000; Ulmer, Williams, \& Preusser, 1997; Chen et al, 2000; Simpson, 2003). At a 2006 conference of leading authorities on the "science of adolescence" sponsored by the National Academy of Sciences, experts cited "the tinderbox in the teenage brain" generating "difficulty in controlling their behavior" as the main cause of adolescents' "high rates of accidents... and reckless behaviors in general"
(Dahl, 2006, pp. 7, 15). Another review attributed "adolescents" inclination to engage in risky behavior" to "the temporal gap between puberty, which impels adolescents to thrillseeking, and the slow maturation of the cognitive control system, which regulates these impulses" (Steinberg, 2007, p. 55).

"Teen drivers are different from other drivers," the National Highway Traffic Safety Administration's (2008) discussion. "Saving Teenage Lives," declares:

On the basis of miles driven, teenagers are involved in three times as many fatal crashes as are all drivers. Why do young drivers have such poor driving performance? Three factors work together to make the teen years so deadly for young drivers:

... Inexperience: All young drivers start out with very little knowledge or understanding of the complexities of driving a motor vehicle. Like any other skill, 
learning to drive well takes a lot of time. Technical ability, good judgment and experience all are needed to properly make the many continuous decisions, small and large, that add up to safe driving...

Risk-taking behavior and immaturity: Adolescent impulsiveness is a natural behavior, but it results in poor driving judgment and participation in high-risk behaviors such as speeding, inattention, drinking and driving, and not using a seat belt. Peer pressure also often encourages risk taking.

Greater risk exposure: Teens often drive at night with other teens in the vehicle, factors that increase crash risk.

That NHTSA, like others, fails to assess, or even mention, low socioeconomic status as a risk to teenaged drivers is curious When evaluating the large differences in risks among various racial, ethnic, and regional groups-such as the high rates of homicide among African Americans or motor vehicle deaths among Southernersresearchers typically pursue social and economic explanations (i.e., Fox \& Piquero, 2002). However, conclusions about adolescent risktaking and its causes have been reached without first controlling for the differing socioeconomic conditions in which adolescents and adults live (Reyna \& Rivers, 2008; Casey, 2008; for critique, see Males, 2009).

That such environmental conditions might be important variables in what is called "adolescent risk-taking" is indicated by the fact that for every race and locale, young people ages 15-19 and 20-24 are two to three times more likely to live in households with incomes below federal poverty thresholds than are adults ages 45-64 (US Census Bureau, 2008, 2008a, 2008b). Agebased income stratification is so pronounced that poverty rates averaging below $10 \%$ are found for teenagers in only five of California's 58 counties, versus 32 counties for ages 45-54. Meanwhile average poverty rates of $20 \%$ or higher afflict teenagers in 18 counties, versus none for Californians ages 45-54.

The contribution of socioeconomic status to motor vehicle crash mortality, the largest category of external deaths among Americans ages 15 to 34, deserves comprehensive attention, yet only three studies can be located that even peripherally discuss the subject (AgueroValverde \& Jovanis, 2006; Hasselberg \& Laflamme, 2005, 2003) and one, this author's, that provides only a preliminary sketch (Males, 2007). The present study examines the associations between motor vehicle fatalities, socioeconomic status and related environmental variables among teenagers and adults in California for the purpose of testing the hypothesis that higher levels of poverty more efficiently explains the variance between teenage and adult motor vehicle fatality rates than does innate "adolescent risk-taking."

\section{Methods}

\section{Data description}

This analysis concentrates on characteristics of California resident drivers involved in motor vehicle crashes that caused at least one fatality on public roads, as compiled by the US Department of Transportation's Fatality Analysis Reporting System (FARS, 2008) for the full 1994-2007 period. Ten descriptive variables for drivers and vehicles involved in fatal crashes (single year of age, county of residence, driver's license status, seat belt/restraint use, alcohol or drug intoxication, age of vehicle driven, size of vehicle driven, number of vehicle occupants, and percent of accidents involving single vehicles or vehicle rollover) were entered into the database in conjunction with eight environmental variables by county (poverty rate by age, median percapita personal income, per-capita motor-vehicle registrations, per-capita miles of roadway, percent of the labor force that is unemployed, percent of the population licensed to drive, population density per square mile, and percent of all commuter trips that are made by motor vehicle as opposed to public transportation and other modes) from the California Department of Finance's Demographic Research Unit (2008) and the Census (2008, 2008a, 2008b) (see Table $1)$. Driver speed is not included because values are missing for $47 \%$ of cases. The poverty rate is defined by the Census as the percentage of the population living on incomes below federal 
poverty guidelines $(\$ 13,410$ for a family of three in 1999). Where primary data is available only for age groups, values for individual ages were estimated by linear interpolation (Shyrock \& Siegel, 1976).

The analysis excluded two sets of outliers. Drivers under age 16 and over age 74 were excluded to eliminate the effect on mortality of age-related physical limitations, and vehicles that were over 60 years old or which had 10 or more occupants also were excluded. To avoid mathematical adjustments necessary to compensate for the effects of small cell size, only the 35 counties with populations of 100,000 or more in the 2000 census are included; these counties account for $96 \%$ of California's fatal traffic crashes. With these exclusions, 2,065 county-by-age cells with 65,531 drivers involved in fatal motor vehicle accidents over the 14-year study period remained; the elimination of a few cases with missing values for certain variables for the analyses reduced available cases to 65,173 .

Table 1. Characteristics of fatal crash rates by driver age group

\begin{tabular}{|c|c|c|c|c|c|c|c|c|}
\hline Driver age group $\rightarrow$ & All ages & $16-19$ & $20-24$ & $25-34$ & $35-44$ & $45-54$ & $55-64$ & $65-74$ \\
\hline \multicolumn{9}{|c|}{ Driver characteristics } \\
\hline Fatal crashes/100m VMD & 18.69 & 49.47 & 31.59 & 18.07 & 14.85 & 14.33 & 15.67 & 19.19 \\
\hline Fatal crashes/year & 4,681 & 465 & 736 & 1,113 & 996 & 731 & 405 & 236 \\
\hline VMD/driver/year & 10,568 & 4,826 & 9,745 & 12,045 & 12,543 & 11,850 & 9,430 & 6,608 \\
\hline Percent in poverty & $12.0 \%$ & $20.7 \%$ & $23.0 \%$ & $14.7 \%$ & $11.5 \%$ & $8.7 \%$ & $9.0 \%$ & $6.9 \%$ \\
\hline Driver using restraint & $71.5 \%$ & $71.9 \%$ & $67.3 \%$ & $69.2 \%$ & $70.7 \%$ & $73.0 \%$ & $73.5 \%$ & $73.2 \%$ \\
\hline Driver intoxicated & $17.5 \%$ & $15.4 \%$ & $28.0 \%$ & $25.6 \%$ & $20.5 \%$ & $16.7 \%$ & $12.1 \%$ & $7.8 \%$ \\
\hline Percent unlicensed & $14.7 \%$ & $22.2 \%$ & $27.4 \%$ & $24.2 \%$ & $16.1 \%$ & $10.9 \%$ & $7.4 \%$ & $5.5 \%$ \\
\hline Population (000) & $23,698.2$ & $1,946.8$ & $2,390.3$ & $5,112.3$ & $5,345.4$ & $4,302.8$ & $2,740.4$ & $1,860.2$ \\
\hline \multicolumn{9}{|c|}{ Vehicle and crash characteristics } \\
\hline Vehic & 8.57 & 9.56 & 8.48 & 8.52 & 8.60 & 8.29 & 8.32 & 8.78 \\
\hline Vehicle occupants & 1.65 & 2.22 & 1.88 & 1.74 & 1.66 & 1.51 & 1.46 & 1.53 \\
\hline Vehicle size & 1.95 & 1.67 & 1.70 & 1.89 & 2.07 & 2.06 & 2.01 & 1.95 \\
\hline Percent single vehicle & $38.7 \%$ & $51.4 \%$ & $46.2 \%$ & $39.9 \%$ & $36.7 \%$ & $36.3 \%$ & $34.5 \%$ & $36.9 \%$ \\
\hline Percent vehicle rollover & $20.4 \%$ & $28.8 \%$ & $26.0 \%$ & $22.3 \%$ & $19.7 \%$ & $19.6 \%$ & $18.0 \%$ & $16.0 \%$ \\
\hline
\end{tabular}

One complication involves the potential effects of the state's graduated driver's licensing law, effective July 1, 1998, applied to new drivers under age 18. The rates of fatal involvements by drivers ages 16-19 increased relative to older drivers after the graduated licensing law took effect (Masten \& Hagge, 2004; Males, 2007a). The effect of a law change that disproportionately raised teenage fatal crash involvements relative to older drivers' makes the study hypothesis more difficult to validate.

Estimates of the best measure of risk exposure, the average number of vehicle-miles driven (VMD) per driver, are not available for
California. Thus, VMD by driver age and resident county was calculated using a standard, three-step process (McCarthy, 2002). First, estimates of gross vehicle-miles traveled (VMT) and the proportion of gasoline sales to total fuel sales by county available from the California Department of Transportation's Transportation System Information Program (2008) were used to estimate gross personal vehicle-miles traveled by county. Second, the estimate of gross personal VMT per county was prorated according to the proportion of licensed drivers by age tabulated by the California Department of Motor Vehicles (2007) for each county to produce an estimate of gross VMD by age. Since 
teenaged drivers do not drive as much per person as adults, a third adjustment used estimates of VMD per person by age group from the most recent U.S. Department of Transportation's National Household Travel Survey (Bureau of Transportation Statistics, 2001) to estimate VMD by age group for each
California county. The results this estimation technique yielded for VMD by age of California driver are very similar to those of the NHTS, indicating the technique is not biased with regard to estimating the relative proportions of driving by age. Estimates are shown in Table 1.

Table 2. Characteristics of fatal crash rates by county income bracket

\begin{tabular}{|lrrrrr|}
\hline County income bracket $\rightarrow$ & $\begin{array}{c}\text { Richest } \\
\text { fifth }\end{array}$ & $\begin{array}{c}\text { Second } \\
\text { fifth }\end{array}$ & \multicolumn{1}{c}{$\begin{array}{c}\text { Middle } \\
\text { fifth }\end{array}$} & \multicolumn{1}{c}{$\begin{array}{c}\text { Fourth } \\
\text { fifth }\end{array}$} & \multicolumn{1}{c|}{$\begin{array}{r}\text { Poorest } \\
\text { fifth }\end{array}$} \\
\hline \multicolumn{7}{c}{ County characteristics } \\
Income per capita & $\$ 33,370$ & $\$ 25,370$ & $\$ 21,130$ & $\$ 17,470$ & $\$ 14,760$ \\
Poverty rate & $7.6 \%$ & $8.9 \%$ & $11.7 \%$ & $14.4 \%$ & $17.4 \%$ \\
Unemployment rate & $4.2 \%$ & $5.3 \%$ & $6.9 \%$ & $9.2 \%$ & $12.7 \%$ \\
Teens, pct. of population & $6.6 \%$ & $7.9 \%$ & $8.3 \%$ & $9.6 \%$ & $10.0 \%$ \\
Population/square mile & 3,368 & 759 & 736 & 173 & 84 \\
Percent licensed to drive & $87.8 \%$ & $89.9 \%$ & $83.8 \%$ & $85.6 \%$ & $75.8 \%$ \\
Percent of trips by MV & $79.8 \%$ & $87.9 \%$ & $87.3 \%$ & $90.1 \%$ & $91.2 \%$ \\
Percent of trips by transit & $10.4 \%$ & $2.2 \%$ & $3.2 \%$ & $1.2 \%$ & $1.3 \%$ \\
Road miles per capita & 3.84 & 7.52 & 7.87 & 9.81 & 13.03 \\
\hline \multicolumn{7}{c}{ Driver, vehicle, and crash characteristics } & & \\
\hline Fatal crashes/100m VMD & 12.04 & 14.94 & 16.34 & 28.86 & 40.46 \\
Fatal crashes/100k pop & 13.56 & 18.44 & 19.30 & 30.36 & 38.40 \\
Driver using restraint & $72.5 \%$ & $74.9 \%$ & $70.9 \%$ & $69.8 \%$ & $69.4 \%$ \\
Driver intoxicated & $16.8 \%$ & $17.5 \%$ & $16.9 \%$ & $18.4 \%$ & $17.9 \%$ \\
Vehicle age (years) & 8.13 & 8.49 & 8.13 & 9.01 & 9.10 \\
Vehicle occupants & 1.65 & 1.60 & 1.65 & 1.63 & 1.73 \\
Vehicle size & 1.90 & 1.86 & 1.93 & 1.99 & 2.06 \\
Percent single vehicle & $43.4 \%$ & $38.7 \%$ & $38.8 \%$ & $38.9 \%$ & $33.3 \%$ \\
Percent vehicle rollover & $17.2 \%$ & $18.9 \%$ & $20.3 \%$ & $21.6 \%$ & $24.0 \%$ \\
Percent unlicensed & $13.4 \%$ & $14.0 \%$ & $13.8 \%$ & $15.7 \%$ & $16.8 \%$ \\
\hline & Average annual counts & & \\
\hline Drivers in fatal crashes & 578 & 581 & 1,818 & 1,020 & 684 \\
Total population (000) & $4,473.4$ & $3,594.0$ & $10,543.6$ & $3,383.7$ & $1,703.6$ \\
\hline
\end{tabular}

Counties by income level:

Richest fifth: Marin, San Mateo, San Francisco, Santa Clara, Contra Costa, Placer, Alameda;

Second fifth: Santa Cruz, Napa, Orange, Sonoma, El Dorado, Ventura, Santa Barbara;

Middle fifth: San Diego, San Luis Obispo, Solano, Sacramento, Los Angeles, Monterey, Yolo;

Fourth fifth: Riverside, Shasta, Butte, San Joaquin, Humboldt, Stanislaus, San Bernardino;

Poorest fifth: Kings, Kern, Fresno, Madera, Merced, Tulare, Imperial.

\section{Analysis}

The principal outcome measure of interest, fatal crash involvements per 100 million VMD by age of driver and county, was calculated. The summary results are shown in the Appendix.
Appendix Table A shows that counties vary substantially in fatal crash risk, as well as in poverty levels, miles driven per resident, personal income, and related variables. Drivers in Central Valley, northern California, and 
Sierra foothill counties display much higher risks, as well as generally higher poverty and lower personal income levels, than southern coastal and mid-coastal counties.

Driver, vehicle, and fatal crash characteristics are shown by driver age group (Table 1) and by county income bracket for all drivers (Table 2). Fatal crash involvement rates by driver age group and poverty bracket for all drivers are shown in Table 3. Tables $4 \mathrm{a}$ and $4 \mathrm{~b}$ provide cross sections of the characteristics of fatal crash involvements for the drivers with the highest rates, those age 16-17, and those with the lowest rates, age 46-47. Table 5 shows the simple bivariate association between each predictor and fatal crash involvement rates. The driver and county variables were then subjected to hierarchical multiple regression (Table 6) to estimate the most important predictors when all variables were controlled. Multicollinearity diagnostics were conducted to assess covariance, especially with regard to the three major demographic variables (driver age, poverty rate,

Table 3. California driver' fatal crash involvement rates by age and poverty level Poverty quintile, 35 largest California counties, 2000

\begin{tabular}{|c|c|c|c|c|c|}
\hline $\begin{array}{l}\text { Driver } \\
\text { age: }\end{array}$ & $\begin{array}{l}\text { Richest } \\
\text { fifth }\end{array}$ & 2nd fifth & Middle fifth & 4th fifth & $\begin{array}{l}\text { Poorest } \\
\text { fifth }\end{array}$ \\
\hline \multicolumn{6}{|c|}{ Fatal crashes per 100 million VMD by driver age } \\
\hline $16-19$ & 34.35 & 37.98 & 46.56 & 65.73 & 82.76 \\
\hline $20-24$ & 22.05 & 25.99 & 28.08 & 43.92 & 58.15 \\
\hline $25-34$ & 11.61 & 14.10 & 15.71 & 29.40 & 42.43 \\
\hline $35-44$ & 9.36 & 11.72 & 12.69 & 23.85 & 34.29 \\
\hline $45-54$ & 9.17 & 11.81 & 12.37 & 22.39 & 31.56 \\
\hline $55-64$ & 10.41 & 13.05 & 13.69 & 24.08 & 31.73 \\
\hline$\underline{65-74}$ & $\underline{13.18}$ & $\underline{15.14}$ & 17.50 & 26.00 & $\underline{37.22}$ \\
\hline Ages $16-74$ & 12.04 & 14.94 & 16.34 & 28.86 & 40.46 \\
\hline \multicolumn{6}{|c|}{ Percent in poverty, by age group } \\
\hline $16-19$ & $13.5 \%$ & $16.7 \%$ & $21.8 \%$ & $24.3 \%$ & $27.1 \%$ \\
\hline $20-24$ & $15.2 \%$ & $19.6 \%$ & $26.2 \%$ & $27.2 \%$ & $26.9 \%$ \\
\hline $25-34$ & $8.1 \%$ & $10.9 \%$ & $13.5 \%$ & $18.6 \%$ & $22.7 \%$ \\
\hline $35-44$ & $6.6 \%$ & $7.9 \%$ & $10.7 \%$ & $14.0 \%$ & $18.2 \%$ \\
\hline $45-54$ & $5.7 \%$ & $5.9 \%$ & $7.9 \%$ & $10.9 \%$ & $13.3 \%$ \\
\hline $55-64$ & $5.9 \%$ & $6.3 \%$ & $8.3 \%$ & $10.8 \%$ & $13.8 \%$ \\
\hline$\underline{65-74}$ & $5.5 \%$ & $4.9 \%$ & $6.6 \%$ & $7.2 \%$ & $10.1 \%$ \\
\hline$\overline{\text { Ages } 16-74}$ & $7.8 \%$ & $9.6 \%$ & $12.7 \%$ & $1 \overline{5.9 \%}$ & $19.2 \%$ \\
\hline
\end{tabular}

Note: Each poverty quintile consist of seven counties in the 35 county-ranking by percapita income bracket. See Table 2 and Appendix A.

and county per-capita income) and variables that potentially may more efficiently predict the specific criterion of fatal crash involvement risk. Variables were entered into a stepwise multivariate regression in the order of greatest probability of $\mathrm{F}$ as selected by the stepwise program, and the number and order of variables significant at the 0.05 limit shown in Table 6 represents the number of steps and the order of variable entry.

\section{Results}

The results of the analysis of the 18 predictors of fatal crash involvement risk are shown in Tables 1-6. As expected, teen drivers ages 16-19 were 
2.7 times more at risk of fatal crash involvement than the average for all drivers (Table 1). Interestingly, teens involved in fatal crashes were somewhat more likely than older drivers to have been using seat belts or other restraints and less likely to have been intoxicated. Teens also were nearly twice as likely to occupy highpoverty brackets; were driving vehicles that averaged one year older, were substantially smaller, and contained more occupants (Table $1)$; and were considerably more likely to live in low-income counties (Table 2). In turn, drivers at every age level who resided in low-income counties were two to three times more likely to suffer fatal crashes, both per capita and per mile driven, than drivers in the wealthiest counties. These risks, which accelerated at poverty rates of $12 \%$ and higher and county per-capita incomes of $\$ 20,000$ and lower, were in part functions of lower use of restraints, generally older vehicles, and higher proportions of unlicensed drivers, vehicle rollovers, and singlevehicle accidents. Low-income counties also were characterized by high levels of poverty and unemployment, lower population density, and less extensive public transit (Tables 2, 3). The average poverty level for teenagers and young adults in the wealthiest quintile was similar to that of middle-aged drivers in the poorest quintiles, and fatal crash risks for older drivers averaged only slightly lower than those of younger ones subjected to similar poverty levels.

Tables 4a and 4b's cross-section, or "snapshot," showed, as expected, that drivers ages 16-17 suffer overall fatal crash rates four times higher per mile than drivers age 46-47. However, crash rates are more than twice as high per mile driven for age 16-17, and three times higher among age 46-47, in the poorest county income quintile compared to the richest quintile. Comparison of population distributions in the bottom line of each table showed teenagers are considerably more concentrated in poorer counties and age 46-47 is more represented in the richer ones, reflected in teenaged poverty rates

Table 4a. Cross section of fatal crash involvements among California drivers age 16-17 by county income bracket, 1994-2007

\begin{tabular}{|c|c|c|c|c|c|c|}
\hline & \multicolumn{6}{|c|}{ Poverty quintile, 35 largest California counties, 2000} \\
\hline & $\begin{array}{c}\text { All } \\
\text { counties }\end{array}$ & $\begin{array}{l}\text { Richest } \\
\text { fifth }\end{array}$ & $\begin{array}{l}\text { Second } \\
\text { fifth }\end{array}$ & $\begin{array}{l}\text { Middle } \\
\text { fifth }\end{array}$ & $\begin{array}{l}\text { Fourth } \\
\text { fifth }\end{array}$ & $\begin{array}{l}\text { Poorest } \\
\text { fifth }\end{array}$ \\
\hline \multicolumn{7}{|l|}{ Average levels, age 16-17 } \\
\hline Fatal crashes/100m VMD & 55.62 & 41.15 & 47.91 & 48.82 & 76.64 & 89.25 \\
\hline Fatal crashes/100k pop & 15.03 & 12.51 & 14.74 & 12.00 & 21.12 & 23.50 \\
\hline Poverty rate & $17.0 \%$ & $11.0 \%$ & $12.8 \%$ & $15.9 \%$ & $19.7 \%$ & $25.8 \%$ \\
\hline Miles/driver per year & 2,702 & 3,039 & 3,075 & 2,458 & 2,756 & 2,633 \\
\hline Percent licensed to drive & $29.1 \%$ & $32.1 \%$ & $32.9 \%$ & $27.2 \%$ & $29.4 \%$ & $24.0 \%$ \\
\hline Vehicle age (years) & 9.78 & 9.59 & 10.94 & 8.60 & 9.70 & 10.03 \\
\hline Vehicle size & 1.70 & 1.74 & 1.74 & 1.65 & 1.72 & 1.65 \\
\hline Percent single vehicle & $53.0 \%$ & $54.3 \%$ & $52.6 \%$ & $54.6 \%$ & $53.3 \%$ & $50.2 \%$ \\
\hline Percent vehicle rollover & $29.5 \%$ & $22.3 \%$ & $26.7 \%$ & $29.1 \%$ & $33.3 \%$ & $35.5 \%$ \\
\hline Driver using restraint & $74.1 \%$ & $71.7 \%$ & $78.4 \%$ & $78.0 \%$ & $72.2 \%$ & $69.8 \%$ \\
\hline Driver intoxicated & $11.6 \%$ & $10.2 \%$ & $10.0 \%$ & $8.9 \%$ & $13.5 \%$ & $15.4 \%$ \\
\hline Number of occupants & 2.39 & 2.49 & 2.34 & 2.41 & 2.42 & 2.30 \\
\hline Percent unlicensed & $23.9 \%$ & $18.6 \%$ & $22.5 \%$ & $25.0 \%$ & $27.3 \%$ & $25.6 \%$ \\
\hline \multicolumn{7}{|c|}{ Average annual counts, age $16-17$} \\
\hline Drivers in fatal crashes & 147 & 19 & 21 & 53 & 35 & 20 \\
\hline Population & 980,200 & 149,100 & 142,000 & 437,500 & 164,700 & 86,900 \\
\hline
\end{tabular}




\begin{tabular}{|c|c|c|c|c|c|c|}
\hline & \multicolumn{6}{|c|}{ Poverty quintile, 35 largest California counties, 2000} \\
\hline & $\begin{array}{c}\text { All } \\
\text { counties }\end{array}$ & $\begin{array}{l}\text { Richest } \\
\text { fifth }\end{array}$ & $\begin{array}{l}\text { Second } \\
\text { fifth }\end{array}$ & $\begin{array}{l}\text { Middle } \\
\text { fifth }\end{array}$ & $\begin{array}{l}\text { Fourth } \\
\text { fifth }\end{array}$ & $\begin{array}{c}\text { Poorest } \\
\text { fifth }\end{array}$ \\
\hline \multicolumn{7}{|l|}{ Average levels, age $46-47$} \\
\hline Fatal crashes/100m VMD & 14.24 & 8.67 & 11.84 & 12.30 & 22.39 & 31.59 \\
\hline Fatal crashes/100k pop & 17.44 & 10.52 & 14.59 & 15.05 & 27.82 & 37.88 \\
\hline Poverty rate & $9.3 \%$ & $6.0 \%$ & $6.3 \%$ & $8.4 \%$ & $11.5 \%$ & $14.1 \%$ \\
\hline Miles/driver per year & 12,242 & 12,138 & 12,328 & 12,236 & 12,427 & 11,993 \\
\hline Percent licensed to drive & $95.2 \%$ & $98.0 \%$ & $99.3 \%$ & $95.5 \%$ & $96.1 \%$ & $86.0 \%$ \\
\hline Vehicle age (years) & 8.47 & 8.17 & 7.99 & 8.66 & 8.82 & 8.72 \\
\hline Vehicle size & 2.09 & 1.94 & 1.98 & 2.01 & 2.25 & 2.27 \\
\hline Percent single vehicle & $35.4 \%$ & $39.8 \%$ & $31.4 \%$ & $41.5 \%$ & $34.9 \%$ & $29.3 \%$ \\
\hline Percent vehicle rollover & $19.0 \%$ & $12.5 \%$ & $19.7 \%$ & $23.6 \%$ & $16.2 \%$ & $23.1 \%$ \\
\hline Driver using restraint & $71.4 \%$ & $76.3 \%$ & $73.8 \%$ & $66.5 \%$ & $70.9 \%$ & $69.8 \%$ \\
\hline Driver intoxicated & $17.5 \%$ & $18.3 \%$ & $12.7 \%$ & $22.4 \%$ & $16.6 \%$ & $17.2 \%$ \\
\hline Number of occupants & 1.55 & 1.56 & 1.55 & 1.55 & 1.41 & 1.65 \\
\hline Percent unlicensed & $10.9 \%$ & $13.1 \%$ & $6.1 \%$ & $13.5 \%$ & $11.7 \%$ & $9.9 \%$ \\
\hline \multicolumn{7}{|c|}{ Average annual counts, age $46-47$} \\
\hline Drivers in fatal crashes & 167 & 20 & 22 & 64 & 38 & 25 \\
\hline Population & 958,500 & 187,400 & 149,300 & 421,900 & 135,000 & 64,900 \\
\hline
\end{tabular}

approximately 1.8 times higher overall and in every quintile than among middle-agers. The 3.9-fold gap between 16-17 year-olds' and 4647-year-olds' fatal crash rates per mile driven shrinks to 1.5 to 1.8 times higher under reasonably equal poverty levels (e.g., the richest and second richest teen quintiles and versus the fourth richest and poorest quintiles for age 4647).

Tables $4 \mathrm{a}$ and $4 \mathrm{~b}$ also reveal some unexpected patterns. Teens age 16-17 in poorer counties had higher rates of accidents involving vehicle rollover and generally lower rates of driver licensing and miles driven per driver. However, while crash-involved teens in the poorest income quintile did show considerably higher rates of driving while intoxicated and failure to use restraint, these factors did not vary consistently with county income level. Nor were crashinvolved teens in poorer counties driving smaller or older vehicles or carrying more passengers than teens in more affluent counties. For drivers age 46-47, the sharp increase in fatal crash rates from richer to poorer county income quintiles varied chiefly with a rising percentage of crashes involving vehicle rollover, older vehicle age, and greater vehicle size; other variables were more inconsistent. Teens in fatal crashes were somewhat less likely to have been intoxicated and more likely to have used restraints than their middle-aged counterparts.

The simple bivariate correlation shown in Table 5 found 15 of the 19 predictor variables were significantly associated with the fatal crash involvement criterion at the 0.001 level, and one at the 0.01 level. The percentage of the population licensed to drive (negative), poverty rate (positive), county unemployment rate (positive), county per-capita income (negative), driver age (negative), and motor vehicle occupants (positive) showed the strongest associations with fatal crash rates. When subjected to standard diagnostics, these variables showed strong multicollinearity, suggesting most represent various expressions of economic conditions and/or driver age. However, trivariate regressions (not shown) of fatal crash rates with the most direct measures-poverty and driver age (multiple $\mathrm{R}^{2}=0.279$ ), and county income level and driver age (multiple $\mathrm{R}^{2}=0.308$ ) - 
Table 5. Bivariate associations of 18 predictors with fatal crash involvement rates for drivers age 16-74 per billion vehicle-miles driven

\begin{tabular}{|lr|}
\hline Percent of population licensed to drive by age and county & $-.680^{* *}$ \\
\hline Percent of population living on incomes below poverty guidelines by age and county & $.527^{* *}$ \\
\hline Percent of labor force unemployed by county & $.490^{* *}$ \\
\hline Personal income per capita by county & $-.433^{* *}$ \\
\hline Ages of drivers involved in fatal crashes by county & $-.348^{* *}$ \\
\hline Number of occupants in motor vehicle & $.329^{* *}$ \\
\hline Percent of fatal crashes that involve unlicensed drivers by age and county & $.229^{* *}$ \\
\hline Percent of total trips by public transit by county & $-.204^{* *}$ \\
\hline Percent of total trips by motor vehicle by county & $.203^{* *}$ \\
\hline Percent of fatal crashes involving vehicle rollover & $.198^{* *}$ \\
\hline Miles of public roadways per capita by county & $.191^{* *}$ \\
\hline Vehicle miles driven (VMD) per person by age and county & $-.187^{* *}$ \\
\hline Ages of vehicles involved in fatal crashes by driver age and county & $.180^{* *}$ \\
\hline Population per square mile by county & $-.123^{* *}$ \\
\hline Sizes of vehicles involved in fatal crashes by driver age and county & $-.094^{* *}$ \\
\hline Percent of fatal crashes involving single vehicles & $.071^{*}$ \\
\hline Percent of fatal crashes involving driving under the influence of alcohol (DWI) & .046 \\
\hline Percent of drivers using restraint system properly & -.052 \\
\hline Motor vehicle registrations per capita by county & .033 \\
\hline ** $<0.001,{ }^{*} p<0.01$ N 2 2,065 age-by-county combinations. & \\
\hline
\end{tabular}

proved inefficient in explaining variance. Driver age, in particular, explained virtually none of the variance in crash rates once poverty level was controlled and just $12 \%$ of the variance once county income was controlled, and the predictor pairs together accounted for less than one-third of total variance in both cases. This suggests that other variables that covary with economic status and age may prove better operational representations of fatal crash risk, a question testable by multivariate regression.

Of the 18 variables entered in the hierarchical multiple regression shown in Table 6, eight remained significant predictors accounting for three-fifths of the total variance in fatal crash risk for all drivers $\left(\mathrm{R}=0.786\right.$ adjusted $\mathrm{R}^{2}=0.616$, $\mathrm{p}=0.000$ ). Poverty and county incomes dropped out as significant predictors and driver age became a minor predictor of fatal crash risk. These were replaced by two major correlates (percent of the population licensed to drive by age and county, and county unemployment rate) and several minor ones (miles driven per year by driver age and county, percent of total trips in the county that involved public transportation, vehicle age by driver age and county, and population per square mile by county). These variables appeared to more efficiently operationalize the general economic measures as driving-related factors. Driver age remained a significant predictor even after these variables were controlled, though it accounted for just $3 \%$ of total variance and 5\% of explained variance.

\section{Discussion}

California drivers of all ages living in poorer areas suffer substantially higher fatal crash rates than those in richer areas. The relationship between poverty and income status and fatal crash risk is strong and consistent both between and within driver age groups. Teenagers are more likely than older adults to live in lowincome counties (16-19 year-olds comprise $10.6 \%$ of poorer Tulare County's population age 16-74, compared to $5.4 \%$ of affluent Marin County's), and, within every county, younger ages suffer poverty levels approximately twice those of older adults. 
Table 6. Hierarchical multiple regression of predictors of fatal crash risk, drivers age 16-74

\begin{tabular}{|c|c|c|c|c|c|c|c|c|}
\hline \multirow[b]{2}{*}{ Variable } & \multicolumn{3}{|c|}{ Regression coefficients } & \multirow{2}{*}{$\begin{array}{c}\text { Multiple } \\
\text { R }\end{array}$} & \multirow[b]{2}{*}{$\mathrm{R}^{2}$} & \multirow{2}{*}{$\begin{array}{c}\text { Adjusted } \\
\mathrm{R}^{2}\end{array}$} & \multirow{2}{*}{$\begin{array}{c}\text { Standard } \\
\text { error }\end{array}$} & \multirow{2}{*}{$\begin{array}{c}\text { Change } \\
\text { in } R^{2}\end{array}$} \\
\hline & Beta & $\mathrm{T}$ & $p$ & & & & & \\
\hline Percent licensed to drive & -0.527 & -33.504 & 0.000 & 0.680 & 0.463 & 0.463 & 20.158 & 0.463 \\
\hline Unemployment rate & 0.239 & 14.520 & 0.000 & 0.740 & 0.548 & 0.547 & 18.503 & 0.085 \\
\hline Driver age & -0.200 & -13.538 & 0.000 & 0.760 & 0.578 & 0.578 & 17.875 & 0.030 \\
\hline Miles driven per year & -0.134 & -9.493 & 0.000 & 0.774 & 0.599 & 0.598 & 17.441 & 0.020 \\
\hline Percent trips by transit & -0.260 & -7.134 & 0.000 & 0.781 & 0.610 & 0.609 & 17.187 & 0.012 \\
\hline Vehicle age & 0.066 & 4.755 & 0.000 & 0.784 & 0.614 & 0.613 & 17.102 & 0.004 \\
\hline Population/square mile & 0.144 & 4.111 & 0.000 & 0.786 & 0.618 & 0.616 & 17.036 & 0.003 \\
\hline (Constant) & 5.555 & 5.567 & 0.000 & & & & & \\
\hline
\end{tabular}

Note: $n=2,065$ county-by-age combinations including 65,173 fatal crash involvements by California residents ages $16-74$ in $1994-2007$ in the 35 counties with a 2000 population of 100,000 or more, comprising $95.6 \%$ of the fatal crashes statewide.

Teenaged drivers differ from older adults in significant ways other than age. First, not only are teenagers as a population poorer and more concentrated in lower income counties, those involved in fatal crashes were driving vehicles that averaged more than one year older and were substantially smaller compared to older adults'. What we call "teenage risk," at least in terms of traffic fatality, appears less a function of agebased hazards than it is of a larger "poverty risk" that boosts traffic fatality rates among adult drivers as well. That young age is reduced to a marginal predictor of fatal crash risk when socioeconomic factors are controlled (especially given that this analysis excludes more accidentprone drivers 75 and older to prevent the olderage "U-shaped" crash-rate curve that dilutes young-age effects) suggests that environments are pivotal contributors to young-driver risks.

Second, unexpectedly, teenaged drivers involved in fatal crashes were not taking greater risks than their adult counterparts. Teen drivers were slightly more likely to have used seat belts and other restraints and were less likely to have been intoxicated than were adults 20 and older; teens appeared similar to middle-aged drivers in these respects. One possibility is that teenagers, being less experienced drivers, get into fatal crashes under a wider variety of circumstances. A potentially useful factor not measured by FARS is years of driving experience, which would help sort out whether driver age or driving experience is more closely related to fatal crash risk.

Third, another unexpected finding was that even though younger teen drivers ages 16-17 in poorer counties suffered strongly elevated rates of fatal crashes, particularly those involving vehicle rollover and unlicensed drivers, other variables (smaller and older vehicles, single vehicles, driver intoxication and failure to use restraints, and more vehicle occupants) did not vary consistently with poverty rate and county income level except for teens in the poorest quintile. A similar pattern is evident among drivers age 46-47, in which vehicle rollover propensity was the only consistent driver- and vehicle-level correlate of the higher crash rates associated with lower income and higher poverty levels. There are many potential explanations. One is that even in richer counties, impoverished drivers may disproportionately be involved in crashes. Further, there may be an intangible "vehicle risk" that is not completely measured by vehicle age and size but may be better reflected in vulnerability to rollover. Rollover propensity, in turn, appears to be complex, involving larger vehicles with high centers of gravity such as vans and SUVs; smaller vehicles that are poorly maintained, lack modern stabilizing features and restraints, and/or are struck by larger ones; driver steering skills; and road hazards found more commonly in rural 
areas (NHTSA, 2008a). The complex interactions between vehicle rollover propensity by type of accident (single-vehicle versus collision), vehicle age, size, and type; driver age and poverty; and county rurality and other characteristics appear a productive area for future analysis.

How does an environment of poverty translate into greater traffic hazard? It should be emphasized that this study finds that poorer environments, not necessarily individual poverty, are connected to higher risk. One risk is self-evident: the manifestly higher fatal crash rates, both per-capita and per mile driven, in poorer counties exposes all resident drivers to disproportionately higher risks of fatal involvement with each other, as the higher proportion of collision accidents in poorer counties indicates. Further, low-income drivers tend to drive older, less-maintained vehicles (Bureau of Transportation Statistics, 2001). Other connections are more speculative. Poorer counties have lower tax bases, possibly leading to less maintained local roads, lower quality emergency response and health care, and deficient public transportation. Counties with high proportions of teenagers, and of poverty and unemployment, also tend to have much lower population densities than more affluent, older-populated counties, which may be tied to a variety of more hazardous conditions including scarcer public transportation and slower emergency response.

Particularly at young ages, poverty is associated with considerably lower rates of driver's licensing and less driving overall, leading to slower acquisition of driving experience that reduces crash risk (see Dee \& Evans, 2001). For example, drivers ages 16-19 in affluent counties such as Marin and San Mateo, despite driving 2,000 to 3,000 more miles each every year, have just one-third the per-person risk and one-fifth the per-mile risk of fatal crash involvement than do teenaged drivers in impoverished counties such as Humboldt and Tulare. Evidence that teenagers who are least at risk tend to be those who are licensed to drive and who drive the most, factors that covary with higher socioeconomic status, challenges the assumption that more teenagers driving more miles necessarily elevates fatality hazards. To assess directly the effect of driver inexperience, a data set that includes not just drivers' ages but years of driving experience (a variable not provided by FARS), would be necessary. It is clear that what aspects of poverty, income, unemployment, rates of driver licensing, population age structure, population density, and public transportation prevalence interact in what ways to contribute to unlicensed driving, driving while intoxicated, driving without restraints, and vehicle rollover incidence that in turn contribute to fatal crash risk are complexities that remain to be explored.

These findings dispute popular theories now dominating "adolescent risk" discussion in the US. Theories attributing differences between teenage and adult behaviors to adolescents' innate immaturities and risk-taking (Reyna \& Rivers, 2008; Steinberg, 2007; Dahl, 2006; Hedlund, Shults, \& Compton, 2003; Ulmer, Williams, \& Preusser, 1997; Chen et al, 2000) have emerged and proliferated without considering societally-imposed disadvantages such as poverty and low-income environments. The claim that risk-taking is innate to teenagers has led to advocacy for policies curtailing teenage driving and perhaps even banning it altogether, strategies more likely to add to teenage risks by preventing youths from gaining necessary driving experience. In fact, the most effective measures to combat high rates of motor vehicle fatality may emerge from careful analyses necessary to understand how California's excessive rates of poverty, particularly among young people, and deficient driving conditions in poorer areas interact to substantially elevate fatality risks. 


\section{References}

Aguero-Valverde J. \& Jovanis P.P. (2006). Spatial analysis of fatal and injury crashes in Pennsylvania. Accident Analysis \& Prevention, 38:618-625.

Blum, R.W., Beuhring, T. \& Rinehart, P.M. (2000). Protecting teens: Beyond race, income and family structure. Center for Adolescent Health, University of Minnesota. URL: http://www.allaboutkids.umn.edu/cfahad/Ethnicity.pdf. Accessed December 5, 2009.

Bureau of Transportation Statistics (2001). National household travel survey, 2001. Washington, DC: US Department of Transportation, Table A-17. At: http://www.bts.gov/publications/highlights_of_the_2001_national_household_travel_survey/. Accessed December 5, 2008.

California Department of Motor Vehicles (2007). Teenage drivers' licenses by age, 1995-2004. Provided by Research and Development Branch, David DeYoung, Chief.

California Department of Transportation, Transportation System Information Program (2008). California motor vehicle stock, travel, and fuel forecast (annual). Sacramento, CA: California Department of Transportation. At: http://www.dot.ca.gov/hq/tsip/otfa/mtab/. Accessed January 10, 2009.

Casey, B.J., Getz, S. \& Galvan A. (2008). The adolescent brain. Developmental Review, 28, 62-77.

Chen, L.H., Baker, S.P., Braver, E.R., \& Guohua, L. (2000). Carrying passengers as a risk factor for crashes fatal to 16- and 17-year-old drivers. Journal of the American Medical Association, 283, $1578-1582$.

Dahl, R.E. (2006). In, Program committee for a workshop on the synthesis of research on adolescent health and development. A study of interactions: Emerging issues in the science of adolescence workshop summary. Washington, DC: National Research Council.

Dee, T., \& Evans, E. (2001). Behavioral policies and teen traffic safety. American Economics Association, AEA Papers and Proceedings, 91, 91-96.

Demographic Research Unit (2008). Race/ethnic population with age and sex detail, 2000-2050. Sacramento, CA: California Department of Finance. At: http://www.dof.ca.gov/HTML/DEMOGRAP/Data/RaceEthnic/Population-0050/RaceData_2000-2050.php. Accessed March 25, 2009.

EPICenter (2008). California injury data online. Sacramento, CA: California Department of Health Services. At: http://www.applications.dhs.ca.gov/epicdata/content/tb_nonfatal.htm. Accessed March 25, 2009.

FARS (Fatality Analysis Reporting System) (2008). Fatality analysis reporting system encyclopedia. Washington, DC: National Highway Traffic Safety Administration. At: http://wwwfars.nhtsa.dot.gov/QueryTool/QuerySection/SelectYear.aspx. Accessed March 22, 2009.

Fox, J.A., \& Piquero, A. (2003). Deadly demographics: Population characteristics and forecasting homicide trends. Crime and Delinquency, 49, 339-359

Hasselberg M., \& Laflamme, L. (2003). Socioeconomic background and road traffic injuries: a study of young car drivers in Sweden. Traffic Injury Prevention, 4, 249-254.

Hasselberg M., \& Laflamme, L. (2005). The social patterning of injury repetitions among young car drivers in Sweden. Accident Analysis \& Prevention, 37, 163-168.

Hedlund, J., Shults, R.A., \& Compton, R (2003). What we know, what we don't know, and what we need to know about graduated driver licensing. Journal of Safety Research, 34, 107-115.

Males, M. (2007). Poverty, not "risk taking," may be the real problem in teenage accidents. The Chronicle of the American Driver and Traffic Safety Education Association, 55, 4-5, 8, 19.

Males, M. (2007a). California's graduated driver license law: Effect on teenaged drivers' deaths through 2005. Journal of Safety Research, 38, 651-659.

Males M. (2009). Does the adolescent brain make risk-taking "inevitable"? A skeptical appraisal. Journal of Adolescent Research, 24, 3-20. 
Masten, S.V., \& Hagge, R.A. (2004). Evaluation of California's graduated driver licensing program. Journal of Safety Research, 35, 523-535.

McCarthy, P.S. Public policy and alcohol related crashes among older drivers. 16th International Conference on Alcohol, Drugs, and Traffic Safety, Montreal, Canada, August 2002. Available at: http://www.econ.gatech.edu/papers/mccarthy_CADTS_paper_SOEwebst_091402.pdf. Accessed December 5, 2008.

NHTSA (National Highway Traffic Safety Administration) (2008). Saving teenage lives. At: http://www.nhtsa.dot.gov/people/injury/newdriver/SaveTeens/sect1.html. Accessed March 25, 2009.

NHTSA (2008a). Rollover. At: http://www.safercar.gov/portal/site/safercar/menuitem.13dd5c887c7e1358 fefe0a2f35a67789/?vgnextoid=de78dc4e3e394110VgnVCM1000002fd17898RCRD. Accessed March 25, 2009.

Reyna, V. \& Rivers, S., eds. (2008). Current directions in risk and decision making (special issue). Developmental Review, 28, 1-152.

Simpson, H.M. (2003. The evolution and effectiveness of graduated licensing. Journal of Safety Research, 34, 25-34.

Steinberg, L. (2007). Risk taking in adolescence: New perspectives from brain and behavioral science. Current Directions in Psychological Science, 16, 55-59.

Shyrock, H.S., \& Siegel, J. (1976). The methods and materials of demography. San Diego, Calif: Academic Press.

Ulmer, R.G., Williams, A.F., \& Preusser, D.F. (1997). Crash involvements of 16-year-old drivers. Journal of Safety Research, 28, 97-103.

US Census Bureau (2008). Single year of age-poverty status. 2006 poverty. Washington, DC: Department of Commerce, Table POV34-1. At: http://pubdb3.census.gov/macro/032007/pov/new34_100.htm. Accessed December 5, 2008.

US Census Bureau (2008a). Census 2000 Summary File 3 (SF 3)-Sample Data, Detailed Tables. Washington, DC: US Department of Commerce. At: http://factfinder.census.gov/servlet/DTGeoSearchByListServlet?ds_name=DEC_2000_SF3_U\&_ lang=en\&_ts=199760803875. Accessed December 5, 2008.

US Census Bureau (2008b). Current Population Survey 2006. Available at: http://www.census.gov/population/www/socdemo/hh-fam/cps2006.html. Accessed December 5, 2008 .

\author{
Author Information \\ Mike Males, Ph.D.* \\ Senior researcher \\ Center on Juvenile and Criminal Justice \\ 440 9th Street \\ San Francisco, CA 94103 \\ Email: mmales@earthlink.net \\ Telephone: (405)219-8539 \\ * corresponding author
}




\section{Appendix A}

Characteristics of 35 counties with $100,000+$ total population, ranked by per-capita income, Ages 16-74

\begin{tabular}{|c|c|c|c|c|c|c|c|c|}
\hline \multirow[b]{2}{*}{ County } & \multicolumn{2}{|c|}{ Fatal crashes per } & \multicolumn{2}{|c|}{ Average annual: } & \multicolumn{2}{|c|}{ Percentage: } & \multirow{2}{*}{$\begin{array}{c}\text { Crashes } \\
\text { unlicensed }\end{array}$} & \multirow{2}{*}{$\begin{array}{c}\text { Percapita } \\
\text { income }\end{array}$} \\
\hline & $100 \mathrm{~m}$ VMD & 100k pop & Population & Crashes & income & licensed & & \\
\hline Marin & 7.11 & 9.57 & 185,114 & 18 & $6.6 \%$ & $95.2 \%$ & $20.6 \%$ & $\$ 44,962$ \\
\hline San Mateo & 8.16 & 10.53 & 517,595 & 55 & $5.7 \%$ & $91.8 \%$ & $16.9 \%$ & $\$ 36,045$ \\
\hline El Dorado & 21.46 & 26.19 & 116,720 & 31 & $7.1 \%$ & $96.4 \%$ & $22.9 \%$ & $\$ 34,556$ \\
\hline San Francisco & 16.44 & 9.44 & 618,992 & 58 & $10.9 \%$ & $80.1 \%$ & $20.2 \%$ & $\$ 32,795$ \\
\hline Napa & 18.82 & 20.59 & 88,817 & 18 & $7.7 \%$ & $89.1 \%$ & $24.2 \%$ & $\$ 30,615$ \\
\hline Monterey & 21.79 & 23.30 & 276,259 & 64 & $12.3 \%$ & $79.9 \%$ & $23.6 \%$ & $\$ 27,963$ \\
\hline Santa Clara & 10.88 & 12.17 & $1,229,324$ & 150 & $7.2 \%$ & $92.4 \%$ & $19.9 \%$ & $\$ 26,680$ \\
\hline Santa Barbara & 15.61 & 16.70 & 285,654 & 48 & $14.1 \%$ & $86.6 \%$ & $26.2 \%$ & $\$ 26,396$ \\
\hline San Diego & 15.00 & 17.14 & $2,031,613$ & 348 & $11.4 \%$ & $87.5 \%$ & $21.4 \%$ & $\$ 26,395$ \\
\hline Contra Costa & 15.73 & 15.95 & 686,254 & 109 & $6.9 \%$ & $90.2 \%$ & $24.5 \%$ & $\$ 25,826$ \\
\hline Los Angeles & 15.80 & 16.12 & $6,764,270$ & 1,091 & $15.8 \%$ & $78.3 \%$ & $24.6 \%$ & $\$ 25,724$ \\
\hline Yolo & 19.71 & 22.63 & 125,639 & 28 & $19.7 \%$ & $79.0 \%$ & $25.4 \%$ & $\$ 25,560$ \\
\hline Orange & 12.56 & 14.01 & $2,047,946$ & 287 & $9.4 \%$ & $88.7 \%$ & $19.4 \%$ & $\$ 24,600$ \\
\hline Santa Cruz & 18.25 & 17.87 & 187,433 & 34 & $12.1 \%$ & $88.2 \%$ & $24.1 \%$ & $\$ 23,059$ \\
\hline Placer & 19.84 & 25.99 & 185,515 & 48 & $5.7 \%$ & $94.2 \%$ & $19.6 \%$ & $\$ 22,926$ \\
\hline Ventura & 16.54 & 17.34 & 539,267 & 94 & $8.4 \%$ & $90.0 \%$ & $20.6 \%$ & $\$ 21,864$ \\
\hline Sonoma & 22.63 & 21.59 & 328,147 & 71 & $7.9 \%$ & $92.0 \%$ & $20.9 \%$ & $\$ 21,731$ \\
\hline Sacramento & 21.32 & 21.59 & 881,282 & 190 & $12.3 \%$ & $84.7 \%$ & $24.3 \%$ & $\$ 21,142$ \\
\hline Alameda & 11.53 & 13.36 & $1,050,605$ & 140 & $10.4 \%$ & $86.6 \%$ & $25.7 \%$ & $\$ 20,683$ \\
\hline Solano & 16.25 & 20.36 & 282,113 & 57 & $7.4 \%$ & $85.3 \%$ & $23.0 \%$ & $\$ 20,165$ \\
\hline San Luis Obispo & 17.73 & 21.18 & 182,411 & 39 & $13.7 \%$ & $86.8 \%$ & $22.7 \%$ & $\$ 19,365$ \\
\hline Shasta & 28.06 & 33.48 & 119,489 & 40 & $14.1 \%$ & $92.8 \%$ & $24.1 \%$ & $\$ 18,689$ \\
\hline Butte & 33.20 & 39.88 & 146,513 & 58 & $19.6 \%$ & $87.3 \%$ & $23.1 \%$ & $\$ 17,738$ \\
\hline Madera & 41.32 & 44.14 & 87,875 & 39 & $18.6 \%$ & $70.9 \%$ & $29.7 \%$ & $\$ 17,517$ \\
\hline San Joaquin & 31.12 & 31.87 & 393,161 & 125 & $15.7 \%$ & $79.6 \%$ & $28.6 \%$ & $\$ 17,365$ \\
\hline Stanislaus & 34.77 & 30.19 & 309,679 & 94 & $14.4 \%$ & $84.1 \%$ & $22.8 \%$ & $\$ 17,203$ \\
\hline San Bernardino & 26.16 & 28.80 & $1,207,759$ & 348 & $13.9 \%$ & $79.7 \%$ & $24.2 \%$ & $\$ 16,913$ \\
\hline Riverside & 29.11 & 29.14 & $1,112,770$ & 324 & $12.8 \%$ & $78.0 \%$ & $25.9 \%$ & $\$ 16,856$ \\
\hline Tulare & 52.36 & 47.11 & 251,702 & 119 & $20.5 \%$ & $75.6 \%$ & $28.9 \%$ & $\$ 15,848$ \\
\hline Kings & 42.14 & 36.48 & 93,214 & 34 & $17.3 \%$ & $61.3 \%$ & $27.1 \%$ & $\$ 15,760$ \\
\hline Fresno & 39.56 & 38.51 & 554,441 & 214 & $19.6 \%$ & $76.4 \%$ & $29.7 \%$ & $\$ 15,495$ \\
\hline Kern & 37.11 & 37.28 & 468,513 & 175 & $18.2 \%$ & $76.5 \%$ & $26.6 \%$ & $\$ 14,682$ \\
\hline Merced & 44.67 & 47.97 & 145,190 & 70 & $19.1 \%$ & $76.8 \%$ & $24.8 \%$ & $\$ 14,257$ \\
\hline Imperial & 28.14 & 33.47 & 102,652 & 34 & $20.3 \%$ & $78.1 \%$ & $20.8 \%$ & $\$ 14,006$ \\
\hline Humboldt & 30.55 & 32.42 & 94,287 & 31 & $19.6 \%$ & $90.7 \%$ & $22.9 \%$ & $\$ 13,239$ \\
\hline Total & 18.69 & 19.75 & $23,698,213$ & 4,681 & $12.8 \%$ & $83.3 \%$ & $24.1 \%$ & $\$ 22,418$ \\
\hline
\end{tabular}

